\title{
PENGARUH KOMPETENSI, MOTIVASI, LINGKUNGAN KERJA DAN PENGAWASAN KERJA TERHADAP KINERJA PEGAWAI PADA KANTOR PELAYANAN PAJAK MADYA MEDAN
}

\author{
Muhammad Joni Hidayat \\ Universitas Islam Sumatera Utara \\ mhd.jonihidayat@gmail.com
}

\begin{abstract}
The purpose of this study is to examine and explain how the influence of competence, motivation, work environment and work supervision on employee performance at the Medan Middle Tax Service Office. The research sample of 95 people. Based on the analysis results obtained there is a significant influence between competence on employee performance, because according to the results of the analysis of tcount> t-table (2.862> 1.67) at $n=95$ with a significance level of $95 \%$., There is a significant influence between motivation on employee performance, because the analysis results of tcount $>t$-table $(2.588>1.67)$ at $n=95$ with a significance level of $95 \%$, There is a significant influence between the work environment on employee performance, because according to the results of $t$-analysis $>t$-table $(2,046>1,67)$ at $n=96$ with a significance level of $95 \%$, there is a significant influence between supervision on employee performance because according to the results of the analysis of $t>$ table $t(1.794>1.67)$ at $n=96$ with a significance level of $95 \%$. count $>$ $F$ table (109,995> 2.48) with the numerator $d k 4$ and the number 90 denominator together (multiple) there is a positive and significant effect on competence, motivation, work environment, and supervision of the performance of employees of the Tax Office M adya Medan. Thus the hypothesis proposed is accepted.
\end{abstract}

Keyworld : competence, motivation, work environment, supervision and employee performance

ABSTRAK : Tujuan penelitian ini adalah untuk menguji dan menjelaskan bagaimana pengaruh kompetensi, motivasi, lingkungan kerja dan pengawasan kerja terhadap kinerja pegawai pada Kantor Pelayanan Pajak Madya Medan. Sampel penelitian sebanyak 95 orang. Berdasarkan hasil analisis diperoleh terdapat pengaruh signifikan antara kompetensi terhadap kinerja pegawai, karena menurut hasil analisis thitung $>t$-tabel $(2,862>1,67)$ pada $n=95$ dengan taraf sifgifikansi 95\%., Ada pengaruh yang signifikan antara motivasi terhadap kinerja pegawai,karena hasil analisis thitung > t-tabel $(2,588>1,67)$ pada $n=95$ dengan taraf sifgnifikansi $95 \%$, Ada pengaruh yang signifikan antara lingkungan kerja terhadap kinerja pegawai,karena menurut hasil analisis thitung > t-tabel $(2,046>1,67)$ pada $n=96$ dengan taraf sifgnifikan 95\%, Ada pengaruh yang signifikan antara pengawasan terhadap kinerja pegawai karena menurut hasil analisis thitung > t-tabel $(1,794>1,67)$ pada $n=96$ dengan taraf sifgifikan 95\%.Nilai F-hitung $>F$ tabel $(109,995>2,48)$ dengan $d k$ pembilang 4 dan dk penyebut 90secara bersama-sama (multiple) terdapat pengaruh positif dan signifikan kompetensi, motivasi, lingkungan kerja, danpengawasan terhadap kinerja pegawai Kantor Pelayanan Pajak Madya Medan. Dengan demikian hipotesis yang diajukan diterima kebenarannya.

Keyworld : $\quad$ kompetensi, motivasi, lingkungan kerja, pengawasan dan Kinerja Pegawai

\section{Pendahuluan}

Sumber daya manusia sebagai salah satu elemen utama dari organisasi merupakan hal yang sangat penting karena faktor manusia sangat berperan dalam mencapai tujuan organisasi. Sumber daya manusia tidak saja membantu organisasi dalam mencapai tujuannya tetapi juga membantu menentukan apa yang benar-benar dapat dicapai dengan sumber daya yang tersedia. Pengelolaan Sumber Daya Manusia (SDM) saat ini merupakan suatu keharusan dan bukan lagi merupakan suatu pilihan apabila organisasi ingin berkembang. Organisasi yang memiliki sumber daya manusia yang baik adalah sebagai modal agar dapat bersaing dengan organisasi lain yang lebih maju. Kompetisi antar organisasi semakin ketat, karena organisasi 
tidak hanya dihadapkan pada persaingan dalam negeri, tetapi juga luar negeri. Menghadapi situasi dan kondisi tersebut, organisasi harus menentukan strategi dan kebijakan manajemennya, khususnya dalam bidang Sumber Daya Manusia (SDM).

Kantor Pelayanan Pajak Madya Medan adalah organisasi pemerintahan, yang mana dalam menjalankan aktivitasnya sehari-hari tergantung pada faktor sumber daya manusia dalam hal ini pegawai. Karena pegawai yang dapat menggerakkan suatu organisasi dengan menghubungkan segenap tenaga, pikiran, bakat, kreativitas demi kelangsungan organisasi itu. Peran atasan senantiasa dituntut untuk bersikap kritis, cakap, cermat dalam menjalankan tugasnya, sehingga pekerjaan yang telah ditetapkan dalam organisasi tersebut dapat berjalan dan berhasil dengan baik, dan pimpinan harus dapat menggerakkan bawahannya untuk bekerja secara efektif sehingga tujuan Kantor Pelayanan Pajak Madya Medan tercapai sesuai dengan target yang telah ditetapkan. Pegawai merupakan salah satu unsur organisasi yang paling dinamis, dengan demikian kedudukan manusia dalam organisasi tidak dapat disamakan dengan unsur-unsur lain, sehingga didalam pengelolaan pegawai seorang pemimpin harus benar-benar mampu mengelola pegawai dengan baik agar pegawai memiliki dedikasi yang baik terhadap organisasi. Pegawai sebagai sumber daya manusia ikut memegang peranan sentral dalam mencapai tujuan organisasi.

Menurut Rivai (2009:88) menjelaskan kinerja pegawai adalah perilaku nyata yang diperlihatkan oleh pegawai sebagai prestasi kerja yang dihasilkan sesuai dengan peranannya dalam organisasi. Dengan demikian dapat dikatakan bahwa kinerja adalah prestasi kerja seseorang, baik secara kuantitas maupun secara kualitas. Dalam meningkatkan kinerja pegawai di Kantor Pelayanan Pajak Madya Medan diduga bahwa kompetensi yang dimiliki para pegawai akan meningkatkan kinerja Kantor Pelayanan Pajak Madya Medan.

Dari pengamatan awal yang penulis lakukan di Kantor Pelayanan Pajak Madya Medan bahwa kompetensi pegawai masih perlu peningkatan dengan cara mengirimkan pegawai untuk mengikuti diklat, seminar, pendidikan dan pelatihan yang relevan secara rutin sesuai dengan jenjang kepangkatan/jabatan yang dimiliki pegawai. Hal ini diperlukan karena kompetensi yang dibutuhkan oleh setiap level jabatan di Kantor Pelayanan Pajak Madya Medanitu berbeda-beda. Pegawai yang mempunyai kompetensi akan bekerja dengan fokus dan bekerja sesuai dengan keahliannya. Dengan demikian pegawai akan menjadi efektif dan efisien bagi organisasi.

Selain kompetensi, hal penting lainnya untuk mendorong kinerja yang baik bagi pegawai Kantor Pelayanan Pajak Madya Medan adalah motivasi. Dengan adanya motivasi yang tinggi akan menciptakan sebuah komitmen terhadap apa yang menjadi tanggung jawabnya dalam menyelesaikan setiap pekerjaan. Motivasi dapat didefinisikan sebagai keadaan dimana usaha dan kemauan keras seseorang diarahkan kepada pencapaian hasil-hasil tertentu. Hasibuan (2012:122) menyatakan bahwa motivasi adalah keinginan untuk bertindak. Motivasi dapat dipastikan mempengaruhi kinerja, walaupun bukan satusatunya faktor yang membentuk kinerja. Menurut Handoko (2011:88), motivasi adalah serangkaian sikap dan nilai-nilai yang mempengaruhi individu untuk mencapai hal yang spesifik sesuai dengan tujuan individu. Motivasi dapat dipastikan mempengaruhi kinerja, walaupun bukan satu-satunya faktor yang membentuk kinerja. Hal ini didukung oleh hasil penelitian yang telah dilakukan oleh Larasati at.al (2014) dan Purwono (2012) yang menyatakan motivasi berpengaruh signifikan terhadap kinerja. Motivasi sangat diperlukan, setiap individu memerlukannya sebagai pendorong agar dapat lebih semangat dalam melaksanakan pekerjaannya. Motivasi seseorang untuk bekerja biasanya melibatkan faktor-faktor individual dan organisasi. Motivasi dapat berbentuk finansial maupun non finansial seperti adanya pemberian pujian, fasilitas penunjang kerja, promosi jabatan, komisi, bonus kerja, uang lembur, dan lain-lain. Dengan adanya pemberian motivasi ini, pegawai pun akan semakin puas dan memperkuat komitmennya terhadap organisasi sehingga pegawai akan berusaha untuk berkinerja baik. Namun pemberian motivasi kepada masing-masing individu tentunya berbeda-beda, karena setiap individu memiliki kebutuhan yang berbeda dan pencapaian kerja yang berbeda pula. Fenomena motivasi kerja pegawai diantaranya masih ada pegawai yang datang terlambat ke kantor dan masih ada pegawai pulang sebelum jam kerja. Walaupun persentasenya yang terlambat dan pulang sebelum jam kantor terbilang kecil, namun jika 
hal ini dibiarkan maka akan menjadi virus yang dapat mengganggu motivasi pegawai yang lain.

Faktor lain yang diduga mempengaruhi kinerja pegawai Kantor Pelayanan Pajak Madya Medan adalah lingkungan kerja. Hasil penelitian yang dilakukan oleh Elvandari (2015) dan Rara Saraswati (2015) menunjukkan bahwa lingkungan kerja berpengaruh signifikan terhadap kinerja.Lingkungan kerja menurut Sedarmayanti (2013:52) adalah keseluruhan alat perkakas dan bahan yang dihadapi, lingkungan sekitarnya di mana seseorang bekerja, metode kerjanya, serta pengaturan kerjanya baik sebagai perorangan maupun sebagai kelompok.Lingkungan kerja bertujuan agar dalam melaksankaan pekerjaan tercipta suasana yang tentram, nyaman dan damai sehingga dapat meningkatkan kinerja pegawai. Permasalahan lingkungan kerja pada Kantor Pelayanan Pajak Madya Medan dilihat dari indikator hubungan pegawai dengan wajib pajak, masih sering terjadi konflik. Konflik yang biasa dialami oleh pegawai adalah konflik ketika menerima dan mempelajari keluhan wajib pajak sehingga hal tersebut akan mempengaruhi kemajuan kinerja pegawai.

Faktor berikutnya yang mempengaruhi kinerja pegawai Kantor Pelayanan Pajak Madya Medan adalah pengawasan. Hasil penelitian Tri Dinda (2015) dan Riyanto (2010) menyatakan pengawasan berpengaruh signifikan terhadap kinerja. Menurut pendapat Dwiyanto (2016:107) bahwa pengawasan adalah proses pengamatan dari pada pelaksanaan seluruh kegiatan organisasi untuk menjamin agar supaya semua pekerjaan yang sedang dilaksanakan berjalan sesuai dengan rencana yang telah ditentukan sebelumnya. Oleh karena itu suatu sistem pengawasan yang bail harus dapat segera mencegah penyimpangan-penyimpangan yang terjadi, sehingga berdasarkan penyimpaganpenyimpagan itu dapat diambil tindakan untuk pelaksanaan selanjutnya agar pelaksanaan keseluruhan benar-benar dapat sesuai atau mendekati apa yang direncanakan sebelumnya. Suatu sistem pengawasan dikatakan baik, jika sistem pengawasan itu memenuhi prinsip fleksibilitas. Ini berarti bahwa sistem pengawasan itu tetap dapat dipergunakan, meskipun terjadi perubahan-peruban terhadap rencana diluar dugaan. Misalnya suatu pekerjaan direncanakan selesai dalam waktu hari, berarti bahwa ukuran yang dipergunakan disini tidaklah mengandung prinsip fleksibel. Sistem pengawasan yang ada di Kantor Pelayanan Pajak Madya Medan diterapkan sesuai dengan peraturan yang ada di Direktorat Jenderal Pajak KementerianKeuangan, dimana atasan langsung mengawasi kinerja bawahannya dan jika ada pegawai yang melanggar peraturan dalam bekerja maka pegawai tersebut akan ditindak sesuai dengan peraturan yang berlaku. Walaupun sistem pengawasan sudah diterapkan, akan tetapi masih ada terjadi kesalahan-kesalahan dalam bekerja seperti masih ada pekerjaan yang diselesaikan belum tepat waktu.

Tujuan penelitian ini adalah untuk menguji dan menganalisis pengaruh kompetensi, motivasi, lingkungan kerja dan pengawasan kerja terhadap kinerja pegawai pada Kantor Pelayanan Pajak Madya Medan.

Berdasarkan pada studi empiris dan uraian tersebut diatas, maka disini peneliti bermaksud melaksanakan penelitian dengan judul Pengaruh Kompetensi, Motivasi, Lingkungan Kerja dan Pengawasan Kerja Terhadap Kinerja Pegawai Pada Kantor Pelayanan Pajak Madya Medan.

\section{Metode Penelitian}

\subsection{Populasi dan Sampel}

Populasi dalam penelitian ini adalah pegawai Kantor Pelayanan Pajak Madya Medan yang berjumlah 125 orang. Teknik pengambilan sampel dalam penelitian ini menggunakan Slovin dalam Sekaran dan Bougie (2010:112), berjumlah 95 orang pegawai.

\subsection{Defenisi Operasional}

Terdapat dua variabel dalam penelitian ini, variabel-variabel tersebut adalah Variabel Terikat, yaitu kinerja (Y), Variabel Bebas adalah kompetensi $\left(\mathrm{X}_{1}\right)$, motivasi $\left(\mathrm{X}_{2}\right)$, lingkungan kerja $\left(\mathrm{X}_{3}\right)$, pengawasan kerja $\left(\mathrm{X}_{4}\right)$.

\subsection{Teknik Pengumpulan Data}

Teknik pengumpulan data dilakukan dengan pengumpulan data primer yaitu data yang dikumpulkan dari sumber-sumber asli untuk tujuan tertentu, atau data yang diperoleh dengan survei lapangan yang menggunakan metode pengumpulan data ordinal, yaitu : wawancara, Kuesioner.

\subsection{Teknik Analisa Data}

Teknik analisis data menggunakan validitas dan realibilitas, uji asumsi klasik dengan menggunakan uji Multikolinearitas, Multikolinearitas, Uji Heteroskedastisitas. 
Pengujian Hipotesis menggunakan uji regresi berganda.

\section{HASIL DAN PEMBAHASAN}

\subsection{Analisis Regresi}

Untuk menganalisis data hasil penelitian dengan maksud untuk memperoleh gambaran hubungan fungsional antara antara variabel bebas dengan variabel terikat hal ini dengan menggunakan analisis regresi linier berganda. Berdasarkan analisis regresi linier ganda (Multiple) sebagaimana pada tabel 1 diperoleh koefisien regresi sebagai berikut.

Tabel 1

Koefisien Regresi

\begin{tabular}{|c|c|c|c|c|c|c|}
\hline \multirow{2}{*}{\multicolumn{2}{|c|}{ Model }} & \multicolumn{2}{|c|}{$\begin{array}{l}\text { Unstandardized } \\
\text { Coefficients }\end{array}$} & \begin{tabular}{|l|} 
Standardized \\
Coefficients \\
\end{tabular} & \multirow[t]{2}{*}{$\mathrm{t}$} & \multirow[t]{2}{*}{ Sig. } \\
\hline & & $\mathrm{B}$ & Std. Error & Beta & & \\
\hline \multirow{5}{*}{1} & (Constant) & 23.539 & .709 & & 33.213 & .000 \\
\hline & Kompetenai & 117 & .041 & .293 & 2.862 & .005 \\
\hline & Motivasi & .118 & .046 & .229 & 2.588 & .011 \\
\hline & Lingkungan kerja & .103 & .051 & .233 & 2.046 & .044 \\
\hline & Pengawasan & .090 & .050 & .207 & 1.794 & .076 \\
\hline
\end{tabular}

Berdasarkan Tabel di atas diperoleh koefisien regresi variabel Kompetensi 0,117, Motivasi = 0,118, Lingkungan kerja 0,103 dan pengawasan 0,090 dengan konstanta 23,539, maka dapat dituliskan persamaan regresi sebagai berikut.

$$
\begin{aligned}
& \mathrm{Y}=23,539+0,117 \mathrm{X}_{1}+0,118 \mathrm{X}_{2}+ \\
& 0,103 \mathrm{X}_{3}+0,090 \mathrm{X}_{4}
\end{aligned}
$$

Persamaan di atas menunjukkan konstanta bernilai positip dan nilai koefisien regresi juga positip. Hal ini memberi gambaran bahwa perubahan rata-rata variabel Kinerja Pegawai (Y) tergantung dari perubahan variabel Kompetensi $\left(\mathrm{X}_{1}\right)$, Motivasi $\left(\mathrm{X}_{2}\right)$. Lingkungan kerja $\left(\mathrm{X}_{3}\right)$ dan pengawasan $\left(\mathrm{X}_{4}\right)$. Artinya apabila Kompetensi, Motivasi, Lingkungan kerja dan pengawasan ditingkatkan akan diikuti perubahan/peningkatan Kinerja Pegawai. Perubahan ini merupakan peningkatan apabila bertanda positip dan penurunan atau pengurangan jika bertanda negatif. Hal ini menunjukkan bahwa ada pengaruh Kompetensi, Motivasi, Lingkungan kerja dan pengawasanterhadap kinerja pegawai.

\subsection{Uji Hipotesis}

Untuk mengetahui pengaruh variabel bebas secara parsial terhadap variabel terikat digunakan uji $\mathrm{t}$, dimana dengan ketentuan :

$\mathrm{t}$ - hitung $\leq \mathrm{t}$ - tabel ...............tidak ada pengaruh variabel bebas secara tersendiri terhadap variabel terikat

t- hitung > t- tabel ............... tidak ada pengaruh variabel bebas secara tersendiri terhadap variabel terikat derajat kebebasan $(\mathrm{dk})=\mathrm{n}-2$ dan Tingkat kepercayaan $\alpha=0,05$,

Berdasarkan hasul yang diperoleh nilai -t Kompetensi $=2,862$, sedangkan $\mathrm{t}$-tabel dengan dk 95 (terlampir) sebesar 1,67 maka thitung > ttabel dengan demikian secara parsial ada pengaruh yang signifikan antara Kompetensi terhadap Kinerja Pegawai di Kantor Pelayanan Pajak Madya Medan.

Selanjutnya nilai t Motivasi $=2,588$, sedangkan t-tabel dengan dk 95 (terlampir) sebesar 1,67 maka $t$ hitung $>t$ tabel dengan demikian secara parsial ada pengaruh yang signifikan antara Motivasi terhadap Kinerja Pegawaidi Kantor Pelayanan Pajak Madya Medan.

Nilai t Lingkungan kerja $=2,046$, sedangkan t-tabel dengan dk 95 (terlampir) sebesar 1,67 maka $t$ hitung $>t$ tabel dengan demikian secara parsial ada pengaruh yang signifikan antara Lingkungan kerja terhadap Kinerja Pegawaidi Kantor Pelayanan Pajak Madya Medan.

Nilai $\mathrm{t}$ pengawasan $=1,794$, sedangkan $\mathrm{t}$ tabel dengan dk 95 (terlampir) sebesar 1,67 maka $t$ hitung $>t$ tabel dengan demikian secara parsial ada pengaruh yang signifikan antara pengawasan terhadap Kinerja Pegawaidi Kantor Pelayanan Pajak Madya Medan.

Untuk mengetahui pengaruh variabel bebas secara bersama-sama terhadap variabel terikat digunakan uji-F, (Sudjana, 2013:355) dengan rumus:

$$
: F_{h i t}=\frac{J K_{r e g} / k}{J K_{r e s} /(n-k-1)}
$$


Dimana :

$\mathrm{JK}_{\text {reg }}=$ Jumlah kuadrat regresi

$\mathrm{JK}_{\text {reg }}=$ Jumlah kuadrat residu

$\mathrm{n}=$ Jumlah Sampel

$\mathrm{K}=$ Jumlah varians

Jika : $\mathrm{F}$ hitung > $\mathrm{F}$ tabel : Hipotesis alternatip diterima, $\quad \mathrm{F}$ hitung $<\mathrm{F}$ tabel : Hipotesis alternatip ditolak (Ho diterima). Penelitian ini menggunakan tingkat kepercayaan 95\% $(\alpha=0.05)$. Berdasarkan analisis varians (Anova) sebagai berikut.

Tabel 2

ANOVA

\begin{tabular}{|rl|r|r|r|l|l|}
\hline \multicolumn{1}{|l|}{ Model } & \multicolumn{1}{|l|}{$\begin{array}{l}\text { Sum of } \\
\text { Squares }\end{array}$} & df & Mean Square & F & Sig. \\
\hline \multirow{3}{*}{1} & Regression & 113.918 & 4 & 28.480 & 109.995 & $.000^{\mathrm{b}}$ \\
& Residual & 23.303 & 90 & .259 & & \\
& Total & 137.221 & 94 & & & \\
\hline
\end{tabular}

a. Dependent Variable: Kinerja Pegawai

b. Predictors: (Constant), Pengawasan, Motivasi, Kompetenai, Lingkungan kerja

Berdasarkan tabel di atas diketahui nilai Fhitung sebesar 109,995 sedangkan nilai F-tabel (terlampir) dengan $\mathrm{dk}$ pembilang $4 \mathrm{dan} \mathrm{dk}$ penyebut 90adalah sebesar 2,72 dimana $\mathrm{F}$ hitung > F tabel $(109,995>2,48)$ maka dapat disebutkan bahwa secara bersama-sama (multiple) terdapat pengaruh positif dan signifikan Kompetensi, Motivasi, Lingkungan kerja dan pengawasan terhadap Kinerja Pegawai..

\subsection{Evaluasi}

Berdasarkan hasil analisis data sebagaimana dikemukakan di atas bahwa Kompetensi pegawai di Kantor Pelayanan Pajak Madya Medan umumnya kurang tinggi, Motivasi di Kantor Pelayanan Pajak Madya Medan kurang tinggi, Lingkungan kerja di Kantor Pelayanan
Pajak Madya Medan baik akan tetapi Kinerja Pegawai masih kurang tinggi. Kinerja Pegawai dapat meningkat apabilaKompetensi semakin meningkat, Motivasi semakin tinggi dan Lingkungan kerja semakin baik dan pebgawasab semakin baik, karena hasil analisis regresi dan pengujian hipotesis diperoleh terdapat pengaruh signifikan Kompetensi, Motivasi, lingkungan kerja dan pengawasan terhadap Kinerja Pegawai Apabila Kompetensi, Motivasi, Lingkungan kerja dan pengawasan ditingkatkan $1 \%$ maka Kinerja Pegawai akan naik $1 \%$. Besarnya pengaruh Kompetensi, Motivasi, Lingkungan kerja pengawasan terhadap Kinerja Pegawai dapat diketahui melalui uji determinasi (D) dimana $\mathrm{D}=\mathrm{R}^{2} \mathrm{x}$ $100 \%$. Hasil analisis pada model summary sebagaimana pada tabel 3 sebagai berikut.

Tabel 3

Model Summary

\begin{tabular}{|l|r|r|l|l|l|}
\hline Model & R & R Square & $\begin{array}{l}\text { Adjusted R } \\
\text { Square }\end{array}$ & $\begin{array}{l}\text { Std. Error of } \\
\text { the Estimate }\end{array}$ & $\begin{array}{l}\text { Durbin- } \\
\text { Watson }\end{array}$ \\
\hline 1 & $.911^{\mathrm{a}}$ & .830 & .823 & .50884 & 1.807 \\
\hline
\end{tabular}

a. Predictors: (Constant), Pengawasan, Motivasi, Kompetenai, Lingkungan kerja

b. Dependent Variable: Kinerja Pegawai

Berdasarkan table di atas diperoleh $\mathrm{R}^{2}=$ 0,830 maka $\mathrm{D}=0,830 \mathrm{x} 100 \%$ sehingga $\mathrm{D}=$ 83\%. Dengan demikian pengaruh Kompetensi, Motivasi, Lingkungan kerja dan pengawasan terhadap Kinerja Pegawai sebesar $83 \%$. sedangkan $17 \%$ lagi yang mempengaruhi Kinerja Pegawai ditentukan faktor lain yang tidak diteliti dalam penelitian ini.

\section{KESIMPULAN}

1. Terdapat pengaruh kompetensi terhadap kinerja pegawai Kantor Pelayanan Pajak Madya Medan
2. Terdapat pengaruh motivasi terhadap kinerja pegawai Kantor Pelayanan Pajak Madya Medan

3. Terdapat pengaruh lingkungan kerja terhadap kinerja pegawai Kantor Pelayanan Pajak Madya Medan

4. Terdapat pengaruh pengawasan terhadap kinerja pegawai Kantor Pelayanan Pajak Madya Medan

5. Terdapat pengaruh kompetensi, motivasi, lingkungan kerja, dan pengawasan terhadap 
kinerja pegawai Kantor Pelayanan Pajak Madya Medan.

\section{DAFTAR PUSTAKA}

Ali, A.Y.S., Dahie, A.M., dan Ali, A.A. (2016). Teacher Motivation and School Performance, the Mediating Effect of Job Satisfaction: Survey from Secondary Schools in Mogadishu. International Journal of Education and Social Science Vol. 3 No. 1; January 2016

Barnardin, H. John Joyce E.A. Ressul (2013), Human Resources, Mc Graw Hill, Inc, Singapore.

Dessler. Gary (2015) ManajemenSumberDayaManusia, Jakarta, SalembaEmpat

Dina Rande (2016), Pengaruh Kompetensi Terhadap Kinerja Pegawai Pada Dinas Perhubungan Komunikasi dan InformatikaKabupaten Mamuju Utara, eJurnal Katalogis, Volume 4 Nomor 2, Februari 2016

Dwiyanto, Agus (2016), Reformasi Birokrasi Public Di Indonesia, UGM Press, Yogyakarta

Eka Suhartini (2015), Pengaruh Kompetensi Terhadap Kinerja Pegawai (Studi Perbandingan Antara Fakultas Ekonomi dan BisnisIslam dan Fakultas Syariah dan Hukum UINAM), Jurnal manajemen dan Inspirasi Vol. 2 Nomor 1.

Elvandari,

ErlinaOktafia (2015) PengaruhLingkungan

Kerja

Dan

PengawasanTerhadapKinerjaKaryawan

PT. TripilarBetonmasSalatigaTahun

2014/2015. Skripsi thesis,

UniversitasMuhammadiyah Surakarta

Handoko T. Hani (2011), ManajemenPersonaliadanSumberDayaMan usia, BPFE, Yogyakarta

Hasibuan Malayu S.P, (2012), Manajemen Sumber Daya Manusia, Edisi Revisi, PT Bumi Aksara, Jakarta.

Husnan, Keldjrachman Suad, (2014), Manajemen Personalia, Edisi ke Empat, BPFE Yogyakarta.

Krietner R dan Angelo Kinicki, (2015), Perilaku Organisasi, Salemba Empat Jakarta

Larasati, Sindi., Gilang, Alini. (2014). "Pengaruh motivasi kerja terhadap kinerja karyawan wilayah Telkom Jabar Barat
Utara (Witel Bekasi)". Jurnal Manajemen dan Organisasi 5 (3) : $200-213$

Mangkunegara Anwar Prabu (2015), Sumber Daya Manusia Perusahaan, Cetakan kedua belas, Remaja Rosdakarya, Bandung

Martoyo, Susili (2014), Manajemen Sumber Daya Manusia, Edisi Ketiga, Cetakan Keempat, Ghalia Jakarta

Marwansyah (2010), Manajemen Sumber Daya Manusia, Alfabeta, Bandung

Mathis, Robert L dan Jackson, Jhon H. 2012. Manajemen SDM. Jakarta : Salemba Empat.

Muluk, M.R.K. (2015), Budaya Organisasi Pelayanan Publik, Jurnal Manajemen Pelayanan Kesehatan 08 (1) : 8-20

Nawawi (2011), Manajemen Sumber Daya Manusia: Untuk Bisnis Yang Kompetitif, Gajahmada University Press, Yogyakarta

Nimran, Umar (2009), Perilaku Organisasi. Sidoarjo : Laros

Nitisemito S Alex (2012), Manajemen Personalia, Cetakan Keempat, Ghalia, Jakarta.

Purwono, Joko., Suryaningsih, Sri., Saptaria, Syati (2012), "Pengaruh kompensasi, motivasi dan kompetensi pegawai terhadap kinerja pegawai di Direktorat Usaha, Direktorat Jenderal Perikanan Budidaya, Kementerian Kelautan Dan Perikanan". Journal NeO-Bis 6 (2) : 157 - 170

Qodri Azizy, Abdul (2015), Change Management Dalam Reformasi Birokrasi. Gramedia, Jakarta

Rara Saraswati (2015), Pengaruh Pengawasan Dan Lingkungan Kerja Terhadap Kinerja Karyawan Bagian Pemasaran PT. Indofood sukses Makmur. Tbk di Pekanbaru, JOM FEKON Vol. 2 No. 1 Februari 2015.

Rivai, Vietzal, dan Ella Sagala (2009), Manajemen Sumber Daya Manusia Untuk Perusahaan. Raja Grafindo Persada Jakarta

Riyanto Sujudi (2010), Pengaruh Kepemimpinan, Motivasi, lingungan Kerja Disiplin Kerja, dan Pengawasan Terhadap Kinerja Pegawai Dinas Perindustrian,Perdagangan, Penanaman Modal, Dan Koperasi,Kabupaten Karanganyar, E-Journal STIE-AUB Surakarta

Robbins, Stephen P. (2009). Perilaku Organisasi. Edisi kesepuluh. Jakarta: Indeks Kelompok Gramedia 
Sedarmayanti (2013), Manajemen Sumber Daya Manusia, Reformasi Birokrasi dan Manajemen Pegawai Negeri Sipil, PT. Refika Aditama, Bandung

Siagian, SP (2011) Teori dan Praktek Pengambilan Keputusan, Cetakan II, CV. Haji Masagung, Jakarta

Schuler Randal S and Jackson Susan E, alih bahasa Prawira Hie (2012), Manajemen Sumber Daya Manusia, Penerbit Erlangga Jakarta.

Sugiyono, 2009, Metode Penelitian Kuantitatif, Kualitatif dn R\&D, Cetakan 10, Penerbit Alfabeta Bandung.
Terry George \& Rue, Leslie W alih bahasa Sadeli (2012), Dasar-Dasar Manajemen, Cetakan Ketujuh Bumi Aksara Jakarta.

Triton PB (2012), Paradigma Baru Manajemen Sumber Daya Manusia, Tugu Yogyakarta. (2006), SPSS 12.00 Terapan Riset Statistik Parametrik, Andi Yogyakarta.

Tri Dinda Agustin (2015), Pengaruh Pengawasan dan Disiplin Kerja Terhadap Kinerja Pegawai Kejaksaan Tinggi Riau, E-Jornal.ac.id.

Wibowo,(2016)

Wijaya Tony, 2011, Cepar Menguasai SPSS Untuk Olah \& Interpretasi Data Penelitian, Cahaya Atma Yogyakarta. 